\title{
Tarih Dergisi’nin Mutfağı
}

\section{The Cuisine of The History Journal}

\author{
İlhan Şahin*๑
}

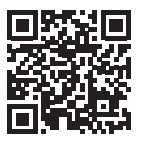

*Prof. Dr., 29 Mayıs Üniversitesi, Edebiyat Fakültesi, Tarih Bölümü, İstanbul, Türkiye

ORCID: I.Ş. 0000-0002-3472-2007

Sorumlu yazar/Corresponding author: İlhan Şahin,

29 Mayıs Üniversitesi, Edebiyat Fakültesi, Tarih Bölümü, İstanbul, Türkiye

E-posta/E-mail: ilsahin40@gmail.com

Başvuru/Submitted: 30.05 .2020 Revizyon Talebi/Revision Requested: 15.06.2020

Son Revizyon/Last Revision Received: 05.07.2020

Kabul/Accepted: 12.07 .2020

\section{Atıf/Citation:}

Şahin, IIlhan. "Tarih Dergisi'nin Mutfağı." Tarih Dergisi - Turkish Journal of History, 71 (2020): 1-14. https://doi.org/10.26650/TurkJHist.2020.001

\section{öz}

Edebiyat Fakültesi, İstanbul Üniversitesi'nin ilk ve en önemli fakültesi olma özelliğini taşır. Bu bağlamda fakülte, başta tarih olmak üzere insanî bilimlerin Türkiye'de kurucusu olmak gibi tarihî bir misyona sahiptir. Bu misyon hem yetiştirdiği bilim insanları hem de eğitim-öğretim ve uluslararası bilimsel periyodik yayınlarda kendini gösterir. Bu periyodik bilimsel yayınlardan en önemlilerinden biri, 1949 yılından bugüne kadar yayınlanan Tarih Dergisi'dir. Ord. Prof. M. Cavid Baysun tarafından tesis edilen dergi, kısa süre içinde önemli periyodik dergiler arasında yerini almıştır. Derginin ürün olarak ortaya çıkmasında iki önemli safhanın olduğunu belirtmek gerekir. Bunlardan biri, dergide yer alacak makalelerin basıma hazır bir hâle getirilmesi; diğeri ise derginin basım aşamasıdır. Bu makalede derginin özellikle 1974-1983 yılları arasındaki basımı ve basım safhası ele alınmakta ve bu bağlamda makalelerin basıma hazır hâle getirilmesi; uzun ve ince bir yol olan Edebiyat Fakültesi Basımevi'ndeki basım süreci üzerinde yoğunlaşılmaktadır.

Anahtar sözcükler: Edebiyat Fakültesi, Tarih Dergisi, mutfak, periyodik dergiler, basım

\section{ABSTRACT}

The Faculty of Letters is foremost among the faculties of Istanbul University. In this context, the faculty has an historic mission as the founder in Turkey of social sciences and, in particular, of history. The faculty's mission is both to nourish scholars and to stand out in both training and education as well as in international scientific periodicals. One of the most important of these periodicals is Tarih Dergisi (The History Journal), which began to be published in 1949. This journal was established by Distinguished Professor M. Cavid Baysun and quickly took its place among the important periodical journals of the day. However, we should take note of two important stages in the preparation of this journal in order for it to become a finished product. The first concerns the articles being put into a form that makes them ready for printing and the second is the printing stage of the journal. This article takes up the preparation for printing and printing stages as they happened between 1974 and 1984. In this regard, we address the matters of making the content ready for printing and also the long and careful path to publication in the printing stage at the Faculty of Letters Printing House.

Keywords: The Faculty of Letters, The History Journal, cuisine, periodical journals, printing 
İstanbul Üniversitesi Edebiyat Fakültesi, Türkiye’nin en eski ve köklü eğitim ve öğretim kurumu olan İstanbul Üniversitesi'nin ilk ve en önemli fakültesi olma özelliğini taşır. Bu bağlamda fakülte, tarihî süreç içinde sadece eğitim ve öğretim bakımından değil, Türk dili ve edebiyatı, tarih, arkeoloji, coğrafya, sanat tarihi, şarkiyat, felsefe ve psikoloji, pedagoji, Batı filolojileri başta olmak üzere insanî bilimlerin Türkiye'de kurucusu olmak gibi tarihî bir misyona sahiptir ${ }^{1}$. Bunun yanında fakülte, gelişmesine paralel olarak farklı disiplinlerde gerçekleştirdiği araştırmalarını ve süreli yayınlarını bilim dünyasına sunma gibi bir misyonu da yüklenmiştir. Başlangıçta çeşitli ihtisas alanlarına ait yazı ve çalışmalar, 1916-1933 yılları arasında çıkan Dârülfünun Edebiyat Fakültesi Mecmuası ve 1917'de Dârülfünun İctimâiyyat Dârülmesâîsi tarafından sosyoloji alanında ilk defa yayımlanmaya başlanan Íctimâiyyat Mecmuası'nın içinde yer almaya başlamıştır³. Türkiye Cumhuriyeti'nin kuruluşunu takip eden yıllarda ise İstanbul Dârülfünunu Edebiyat Fakültesi'nde kurulan Türkiyat Enstitüsü tarafından 1925 'te Türkiyat Mecmuası yayım hayatına girmiştir'. Mehmed Fuad Köprülü'nün müdürlüğünde neşir hayatına başlayan dergi, hâlen süreli yayımlar arasında önemli bir yere sahiptir.

1933 Üniversite Reformu'ndan sonra Edebiyat Fakültesi Tarih Bölümü'nde Tarih Semineri Dergisi / Travaux du Séminaire d'Histoire yayımlanmaya başlar. İmkânsızlıklar içinde çıkan dergi, I/1 (Millî Mecmua Basımevi: İstanbul 1937), I/2 (Millî Mecmua Basımevi: İstanbul 1937) ve II (Millî Mecmua Basımevi: İstanbul 1938) olmak üzere ancak üç sayı yayımlanabilir. Bunu takiben II. Dünya Savaşı’nın dünyayı sarmaladığı bir süreçte yeni bir derginin çıkmasına teşebbüs edilemez. Nihayet 1949 yılında Tarih Bölümü öğretim üyesi Ord. Prof. Cavid Baysun'un gayretleri ve çalışmaları sonucunda bölümde Tarih Dergisi adı altında bir dergi çıkarılmasına karar verilir5. Derginin ilk sayısında Tahrir Heyeti tarafından "Bir Kaç Söz” başlığı altında yazılan ve muhtemelen Cavid Baysun tarafından kaleme alınan yazıda, 11 sene önce Tarih Semineri Dergisi adıyla bir dergi tesis edildiği, derginin sadece üç sayı çıkabildiği, bütün arzulara, teşviklere ve hatta bazı teşebbüslere rağmen canlandırılamadığı

1 Fakültenin tarihçesi ile ilgili olarak bk. Cengiz Orhonlu, "Edebiyat Fakültesi'nin Kuruluşu ve Gelişmesi (1901 -1933) Hakkında Bazı Düşünceler”, Cumhuriyetin 50. Yılına Armağan, haz. İstanbul Üniversitesi Edebiyat Fakültesi, İstanbul 1973, s. 57-70; Cumhuriyetin 50. Yılında İstanbul Üniversitesi, haz. İstanbul Üniversitesi, İstanbul 1973, s. 435-463; M. Taner Tarhan-Ömer Faruk Akün, "Edebiyat Fakültesi”, DİA, X (1994), 399-403.

2 Tamamı 49 sayı (sekiz cilt) olan bu mecmuanın tesisi ve muhtevası için bk. Nurettin Albayrak, "Darülfünun Edebiyat Fakültesi Mecmuası”, DİA, VIII (1993), 525-526. Mecmuadaki makalelerin künyeleri için bk. Fehamettin Başar, "Darülfünun Edebiyat Fakültesi Mecmuası'ndaki Makaleler ve Yazarları”, Tarih Dergisi [TD], say1 38 (2003), 183-234.

3 İlk Türkçe toplum dergisi olan bu mecmuanın tesisi ve muhtevası için bk. Recep Şentürk, "İctimâiyyat Mecmuası", DİA, XXI (2000), 448-449. Bu mecmuadaki yazılar günümüz Türkçesinde yayınlanmıştır (bk. İçtimâiyât Mecmuası, yay. haz. Mehmet Kanar, sayı 1-6, Edebiyat Fakültesi Basımevi, İstanbul 1997).

4 Mecmuanın tesisi ve muhtevası ile ilgili genel bilgi için bk. İsmail Güleç, "Türkiyat Mecmuası”, DİA, XLI (2012), 561-562

5 Derginin tesisi, yayın hayatına başlaması, muhtevası vb. konularla ilgili olarak bk. Mahmut Ak, "50. Sayısında İstanbul Üniversitesi Tarih Dergisi”, TD, say1 50 (2009), s. 259-273; Mahmut Ak, "Tarih Dergisi”, DİA, XL (2011), 79-80. 
hatırlatılır ve bu bağlamda önemli tedkiklerin intişârına vasıta olmak ve husule gelen boşluğu doldurmak için yeni bir derginin çıkarılmasına karar verildiği belirtilir. Ayrıca burada tarihin bütün çağlarına ait araştırmalara açık olacak olan derginin, Tarih zümresinin yeni istidatlarına ait kalem mahsullerinin geniş ölçüde yer alacağı, iki sayısı bir cilt olmak üzere senede iki defa çıkmasının planlandığı ve her sayının 10 formadan aşağı düşmemesine gayret gösterileceği ifade edilir. Derginin sunuş yazısında Tarih Semineri Dergisi'ne atıfta bulunulması, seminer dergisinde kazanılan birikim ve tecrübelerden istifade edildiğinin açık bir ifadesi ve hatta dergilerin adı birbiriyle tam uyuşmasa da birbirinin devamı olduğunu gösterir. $\mathrm{O}$ zamanda dergilerde hakem heyeti vs. gibi oluşumlar olmadığından derginin neşriyle bizzat uğraşan hocalar, yazı işleriyle de meşgul olurlardı. Tarih Dergisi'nin ilk cildinin sayılarında yazı işleriyle meşgul olan hocaların Cavid Baysun, Münir Aktepe ve Orhan F. Köprülü olduğu görülür.

İlk cildin birinci sayısı 1949, ikinci sayısı ise 1950 y1lında İstanbul'da İbrahim Horoz Basımevi'nde basılarak bilim dünyasına sunulan derginin bu sayılarında tertip ve düzen bakımından bazı hususlar dikkati çeker: Bu bağlamda her iki sayıdaki sayfa numaraları ile her biri 16 sayfa olan forma numaraları müteselsil olarak birbirini takip eder. Derginin baş tarafında yer alan İçindekiler kısmında unvanlar yazılmaksızın makale sahibi yazarların adı, soyadı, makale adları ve makalelerin dergi içindeki başlangıç sayfaları yer alır. Burada makalelerin başlangıç sayfalarından da anlaşılacağı üzere her makale dergi içinde tek sayfa numarasından başlar. Bu bakımdan her makalenin tek numaralı sayfada başlayıp çift numaralı sayfada son bulması ve iki makale arasında boş sayfa bırakılmaması, derginin yayın ilkesi olarak görülür. Ayrıca dergide her bir makalenin ilk sayfasına numara verilmeksizin atlama yapılır ve bu sayfayı takiben makalenin çift rakamlı sayfalarının üstüne tek sıra halinde makalenin adı; tek numaralı sayfalarının üstüne ise yazarın adı ve soyadı yazılır. Eğer çift rakamlı sayfanın üstüne makalenin adı, satıra sığmayacak kadar uzun olursa makalenin adında kısaltma yönüne gidilir.

24 makalenin yer aldığı birinci cildin ilk iki sayısında yazısı olan müellifler arasında Tayyib Gökbilgin, Şehabeddin Tekindağ, Münir Aktepe, Orhan F. Köprülü, Zeki Velidi Togan, Cavid Baysun, Hrand Andreasyan, Robert Anhegger, Cemal Tukin, İbrahim Kafesoğlu, Semavi Eyice, Fuad Köprülü, Clemens Emin Bosch ${ }^{6}$, Fevziye Abdullah, Oktay Aslanapa, İsmet Parmaksızoğlu ve İbrahim Artuk gibi seçkin tarihçilerin yer alması, derginin heyecanla ve büyük bir alaka ile bilim dünyasına sunulduğunun işareti olmalıdır. Tabii olarak dergide bu gibi hocaların yazılarının varlı̆̆ı, derginin ilmî ve akademik bakımdan ulu orta değil, yüksek seviyede orijinal yazıları kabul edeceğinin de bir işareti olmuştur. Zaten o dönemde Türkiye’de

6 Eskiçağ tarihi alanındaki akademik çalışmaları ve yayınlarıyla bilinen Clemens Emin Bosch'un hayatı ile ilgili olarak bk. Oğuz Tekin-Nil Türker Tekin, Mülteci Bir Akademisyenin Biyografisi Clemens Emin Bosch (18991955), Suna-İnan Kıraç Akdeniz Medeniyetleri Araştırma Enstitüsü, İstanbul 2007 (Bu bilgiyi vermek lütfunda bulunan Prof. Dr. Kemal Beydilli’ye teşekkür ederim). 
bu seviyede çıkan dergiler, bir elin parmak sayısı kadar azdı. Bu bağlamda tarih alanında Türk Tarih Kurumu'nun yayınladığı Belleten, İstanbul Üniversitesi İktisat Fakültesi’nin yayınladığı İktisat Fakültesi Mecmuası, İstanbul Üniversitesi Türkiyat Mecmuası, Ankara'da Dil ve Tarih-Coğrafya Fakültesi Dergisi ve Vakıflar Genel Müdürlüğü'nün yayımladığı Vakıflar Dergisi ilk akla gelenlerdir.

Tarih Dergisi'nin ikinci cildi (3-4) ve üçüncü cildi (5-6) ikişer sayı halinde çıkar. Bu ciltlerden ikincisi yine İbrahim Horoz Basımevi’nde basılmışken üçüncüsünün Osman Yalçın Matbaası'nda basıldığı dikkati çeker. Derginin Osman Yalçın Matbaası'nda basımı, IX. (sayı 13) cilde kadar devam eder. Bu ciltten itibaren derginin basım yerinde İstanbul Edebiyat Fakültesi Basımevi adı görülmeye başlar ${ }^{7}$ Tarih alanında yaptığı yayınlarla istikrarlı çizgisini devam eden Tarih Dergisi, 1968 yılında kurucusu M. Cavid Baysun'u kaybeder $^{8}$. Bu bakımdan 1969 yılında çıkan 23. sayıdan itibaren derginin hem dış kapağına hem de kapak kısmının yazısını yansıtan iç kısma çerçeve içinde Kurucusu Ord. Prof. M. Cavid Baysun yazılır. Derginin hem tesisi, idaresi ve yayınlanmasında öncü bir rol oynayan hem de sorumluluğunu taşıyan ve meslektaşları arasında İstanbul Beyefendisi olarak anılan Cavid Baysun'un, zaten dergiyle bütünleşmiş olan adının bu şekilde yazılması ve dergide ilânihaye adının yaşayacak olması, şüphesiz o dönemde her biri seçkin öğretim üyesi olan Tarih Bölümü mensuplarının ve talebelerinin hocalarına karşı gösterdikleri bir vefa ve kadirşinaslık örneğidir.

1974 yılında İstanbul Üniversitesi Edebiyat Fakültesi Tarih Bölümü’nde öğrenci iken Tarih Araştırmaları Enstitüsü'nde memur olarak göreve başlamam ve daha sonra Yeniçağ Tarihi Kürsüsü'ne asistan olarak girmem sebebiyle bölümümüzde yayınlanan dergilerle iç içe olmaya başladım. O zaman bölümümüzde Prof. Dr. Münir Aktepe (1917-1996)'nin9 nezaretinde Tarih Dergisi ve Tarih Enstitüsü Dergisi, Prof. Dr. Cengiz Orhonlu (1927-

7 Tarih Dergisi’nin basıldığı yerlerin aynı anlama gelen "basımevi" ve "matbaa" ile ifade edilmesi dikkat çekicidir. Matbaanın Osmanlılara girişi ile birlikte yaygın olarak kullanılan "matbaa" terimi, mühür ve damga basma anlamındaki Arapça "tab" sözcüğü ile ilgilidir. Ancak tab" etme / basım sanatının tarihi çok daha eskilere dayanmaktadır (bu konuda genel bir bilgi için bk. Kemal Beydilli, "Matbaa”, DİA, XXVIII (2003), 105-110). İki kelimenin birleşmesiyle meydana gelen "basımevi” ise şüphesiz kitabın basıldığı yer anlamında "basım" ve "ev" sözcüklerinden meydana gelmektedir. Bu bağlamda bir addan türeyerek meslek bildiren veya o mesleği icra etme anlamına gelen "basmacı" sözcüğünün de "basma-cı" oluşumuyla ortaya çıktığı anlaşılmaktadır.

8 Cavid Baysun'un hayatı ve ilmî faaliyetleri hakkında bk. Münir Aktepe, "Ord. Prof. M. Cavid Baysun”, Belleten, XXXIII/129 (1969), s. 97-113; M. C. Şehabeddin Tekindağ, "Kaybettiğimiz Bir Değer: Ord. Prof. M. Cavid Baysun”, TD, sayı 23 (1969), s. 1-8; Orhan F. Köprülü, “Ord. Prof. Cavid Baysun’un Ardından”, TD, say1 23 (1969), s. 9-12; M. Münir Aktepe, "Baysun, Mehmet Cavit (1899-1968)”, DíA, V (1992), 275-276.

9 Hayatı ve ilmî faaliyetleri için bk. Mücteba İlgürel, "Prof. Dr. Münir Aktepe'nin Hayatı ve Eserleri”, Tarih Enstitüsü Dergisi, say1 15 (1997), s. 1-14; Feridun Emecen, "Prof. Dr. Münir Aktepe’nin Akademik Hayatı", Münir Aktepe, İzmir Yazılarl: Camiler, Hanlar, Medreseler, Sebiller içinde, haz. Fikret Yılmaz, İzmir 2003, s. XXXV-XXXIX; Feridun Emecen, “Aktepe, M. Münir”, DİA, EK-1 (2016), 67-68; Zeki Arıkan, "Yitirdiğimiz Büyük Değer. Münir Aktepe'nin Ardından”, Tarih ve Toplum, sayı 153 (1996), s. 4-8. 
1976)'nun ${ }^{10}$ nezaretinde ise Güney-Doğu Avrupa Araştırmaları Dergisi çıkmaktaydı. $\mathrm{Bu}$ dergilerin Yeniçağ Tarihi Kürsüsü’nde olan hocalarımın nezaretinde çıkması, Cavid Baysun'un ne kadar isabetli hayrülhalefler bıraktığının göstergesi olmalıdır. Bunun yanında bölümün sadece bir kürsüsünde üç derginin birden çıkması, esasında Tarih Bölümü’nün sadece eğitim ve öğretimde değil, uluslararası bilimsel yayın ve araştırmalarda da öncü bir rol oynadığını göstermesi bakımından önemlidir.

Tarih Araştırmaları Enstitüsü ve Yeniçağ Tarihi Kürsüsü’nde görev yaptığım yaklaşık 10 yıl içinde her üç dergi için yazıların toplanması, basıma hazır bir hâle getirilmesi, Edebiyat Fakültesi Matbaası'na intikali, matbaada dizgiye girmesi, provaları çekilen sayfaların tashih için kürsüye gelmesi, tashihlerin matbaada düzeltilmesi, dizilen tashihlerin yeniden kürsüye intikali, burada tekrar gözden geçirilmesi ve nihayetinde dergilerin sorumlusu hocalarımın her makalenin baş tarafına "basıla" diye yazması, ilk formanın önlü arkalı ilk çıkan örneğinin hocalarımıza gönderilerek bir defa daha gözden geçirilmesi ve basım işlemi tamamlandıktan sonra formaların Mücellithane'ye geçmesi, burada bir seri işlemlerden sonra ciltlenip hazır bir hâle getirilmesi ve nihayetinde derginin ilgili kimselere ve kurumlara gönderilmesi hem ayrı ayrı bir süreç hem de uzun ince bir yoldu. Bu süreçte başta Tarih Dergisi olmak üzere diğer dergilerin yayına hazırlanmasında şüphesiz bölüm öğretim üye ve elemanlarının katkısı vardi.

1970’li yıllarda dergilerin yayınlanması esnasında Prof. Dr. Münir Aktepe başta olmak üzere faal olarak görev alan Prof. Dr. Şehabeddin Tekindağ, Prof. Dr. Cengiz Orhonlu, Prof. Dr. Bekir Kütükoğlu ve Doç. Dr. Mücteba İlgürel gibi hocalarımızın yanında asistan veya araştırmacı olan ve bizzat derginin baştan sona yayın sürecinin içinde yer alan Yeniçă̆ Tarihi Kürsüsü ve Tarih Araştırmaları Enstitüsü elemanlarının adlarını burada yad etmem gerekir: F. Çetin Derin, Yusuf Halaçoğlu, İlhan Şahin ve Feridun M. Emecen. Tabii olarak bizler o zamanda hocalarımızın hocası Cavid Baysun'u görememiştik ama dergi çerçevesinde zaman zaman Cavid Baysun ile ilgili hatıraları dinliyorduk. Bir defasında Münir Aktepe hocamızın Tarih Dergisi'nin yeni basılmış bir sayısı elinde iken ve mutluluğu yüzünde okunurken: “Cavid Bey, Tarih Dergisi'nin Bibliothèque Nationale de France (Fransa Millî Kütüphanesi) 'da yer aldı̆̆ını haber alınca çok sevinmişti” sözleri hâlâ hatırımdadır.

Dergilerin yayınlanması ile ilgili olarak her üç derginin de aynı süreçlerden geçtiğini söyleyebiliriz. Tarih Dergisi örneğinde derginin yayınlanmasını ele alacak olursak sırasıyla şöyle bir süreçten geçtiğini belirtmek mümkündür. Dergi, her şeyden önce başta Tarih Bölümü

10 Hayatı ve ilmî çalışmaları için bk. Şahabettin Tekindağ, "Kaybettiğimiz Bir Değer Cengiz Orhonlu", Tarih Dergisi, say1 30 (1976), s. 1-8; Nejat Göyünç, “Cengiz Orhonlu Hayat1-Eserleri-Şahsiyeti”, Türk Kültürü Araştırmaları, XV/1-2 (1976), s. 7-32; Mahmut H. Şakiroğlu, "Prof. Dr. Cengiz Orhonlu 1927-1976”, Belleten, XL/160 (1976), s. 669-686; Yusuf Halaçoğlu, "Hocam Cengiz Orhonlu”, Güney-Doğu Avrupa Araştırmaları Dergisi, XII (1998), s. XI-XIII; İlhan Şahin, “Orhonlu, Cengiz”, DİA, XXXIII (2010), 393-394. 
olmak üzere fakülte mensuplarının yazılarına açıktı. Ayrıca fakülte dışında araştırmalarıyla temeyyüz etmiş olan yerli ve yabancı bilim insanlarının yazıları da hüsnü kabul görürdü. $\mathrm{Bu}$ arada hocam Cengiz Orhonlu, özellikle arşivde çalışan bazı genç araştırıcıların yazısını yayınlanmak üzere elden getirir ve verirdi. Gelen yazılar, daha çok tertip ve düzen bakımından kabaca hocamız Münir Aktepe'nin kontrolünden geçerdi. Bu bağlamda derginin tertip ve düzenine uygun olmayan yazıların dipnotlarında makalelerin ve eserlerin adı, italik olup olmaması, bask1 yeri ve tarihi, sayfa numaraları ile ilgili bir eksiklik vb. olursa bizlerden kütüphaneye giderek tahkik etmemiz istenirdi. Hatta hocamız bu gibi ufak tefek düzeltmeler için: "Oğlum, bu makale sahibi hocanın elinde yazı çok zor çıkar ama yazdı̆̆ı zaman da iyi yazar, ufak tefek pürüzler için yazıyı dergiye küstürmemek lazımdır" der ve elimize yazıyı tutuşturarak ufak tefek pürüzleri kütüphaneden halletmemizi isterdi. Bu bakımdan dışarıdan gelen yazılar arasında basılmamak üzere iade edilen yazılara hiç şahit olmadığımızı belirtmemiz gerekir.

Dergi ile ilgili yazılar basıma hazır hâle getirildikten ve basım ile ilgili resmî işlemler tamamlandıktan sonra makalelerin yer aldığı dosya Edebiyat Fakültesi Basımevi Müdürü olarak sırasıyla hizmet veren Nazım Tahaoğlu, Önder Orhon, Ahmet Avcı ve Yaşar Ulu'ya intikal eder. Buradan dosya dizgiye başlanmak üzere dizgi operatörlerine havale edilir. Matbaada Türkçe metinler başta olmak üzere Latin alfabeli metinler dizgi operatörleri tarafından entertype veya ağızdan söyleyişte entertip denilen dizgi makinesinde dizilir. $\mathrm{Bu}$ makinelerin özelliği, üzerinde daktilo tuşlarına benzer 90 tuşun olması, kurşun harfleri tek satır olarak dizmesi ve dökmesidir. O zaman matbaadaki dizgi operatörleri Şevki Usta olarak bilinen Ali Şevki Bengi ve Adnan Usta olarak bilinen Adnan Adsız idi. Matbaanın diğer kısımlarında görev yapan ustalarımız gibi işlerinin ehli olan bu ustalarımızın her biri bir günde iki forma (32 sayfa), hatta iki buçuk forma (40 sayfa) yazı dizebilmekteydiler. Dergi kendilerine intikal ettikten sonra derginin nasıl bir düzen ve sistemde dizileceğini çok iyi bilirler ve makinede bu düzene göre bir ayarlama yaparlardı. Bu bağlamda dergide dış kapağı takiben iç kapak, tek sayfada başlayan İçindekiler ve yine her biri tek sayfada başlayan makaleler yer alır. İçindekiler kısmı da dahil, her bir makalenin dizilmesine geçilmeden önce dizgi operatörlerimiz tarafından derginin formatına bağlı olarak bir nizampaj verilir.

Gözlemlerimiz ve ustalarımızın verdiği bilgilere göre verilen bu nizampaj bağlamında soldan sağa doğru dizilen her satırın uzunluğu (boyu) 26 katrat olur. Sayfanın üstten aşağıya doğru uzunluğuna ebadı (boyu) ise 40 katrat olarak hesaplanır. İlk sayfada makale adı yazılmadan önce üstte altı satırlık bir boşluk bırakılır. Bu uygulama İçindekiler kısmı için de geçerlidir. Bunu takiben makalenin ismi sağdan ve soldan ortalanarak 12 punto (font) kapital (büyük harf) siyah olarak yazılır. Sonra bu başlığın altına bir katrat yani bir satır boşluk bırakılır ve makale yazarının unvansız adı ve soyadı, üst başlığı ortalayacak şekilde 10 punto, düz (beyaz) ve italik olarak dizilir. Bunu takiben yazar adının ve soyadının altına 
iki katrat yani iki satır boşluk bırakılarak metnin dizimine geçilir. Metnin diziminde 10 punto düz (beyaz) yazı karakteri kullanılır. Yazı karakteri 10 punto ise satırlar 12 punto üzerine dizilir. 12 punto ise 1 katrat olur. Normal makalelerde satır başlarının ara boşluklarını açmak için altı puntoluk boşluk bırakılır. Eğer metin içinde ara başlıklar olursa ara başlıkların üstüne ve altına birer katrat boşluk verilir. Her sayfada alta gelen dip notları ise 8 punto yazı ile dizilir. Ana metin ile dipnotları arasında bir çizgi olursa çizgi ile ana metin arasında altı punto boşluk; çizgi konmadığı takdirde 12 puntoluk bir boşluk bırakılır.

Makalelerin ilk sayfasını takip eden sayfaların üst kısmına gelen sayfa numaraları ve makale adları ile yazar adı ve soyadı, ana metin gövdesinden daha farklı bir şekilde dizilir. Bu bağlamda derginin çift rakamlı sayfasının sol tarafına gövde metnin hizasında sayfa numarası ve bu numaranın soldan sağa doğru hizasında ortalı bir şekilde makalenin adı 8 punto kapital yazı ile yazılır. Tek sayfaların üstüne ise yine gövde metninin hizasında sayfa numarası ve bu numaranın hizasında ortalı olarak yazar adı ve soyad1 8 punto kapital olarak yer alır. Makalelerdeki sayfa üst başlıkları bu şekilde yazıldıktan sonra bir katrat yani bir satır boşluk bırakılır ve asıl metnin dizgisi devam eder.

Dergide sayfa numaraları müteselsil olarak birbirini takip etmesine rağmen iç kapak ve İçindekiler kısmının ilk sayfası ile her makalenin başlangıç sayfası dergi basıldıktan sonra gözükmez. Söz konusu sayfalara dizgi esnasında geçici sayfa numaraları verilir. Bir önceki ve sonraki sayfaların karışmaması için tedbir amaçlı verilen bu sayfa numaraları baskı esnasında çıkartılır. Bizim dizgicilerimizin ve matbaacılığın dilinde bu rakamlara ĭgreti rakam denir.

Entertype adlı dizgi makinesinde dizgi yapılacağı zaman dizgi operatörü klavyenin önüne oturur, satırları dergi nizampajına uygun bir şekilde dizdikçe komutu verir, üst kısımda kanalların içinde matris denen harf kalıpları aşağı kısma düşerek dizilir. Bu işlem esnasında makinenin kazanında eriyen kurşun kalıpların daha sert bir şekilde dökümünün çıkması için antimon denen metal bir elementle karıştırılır. Eriyen kurşun, dizilen satırın üzerine dökülür ve böylece her satır parçalar halinde ortaya çıkmış olur ${ }^{11}$. Dizgide metin arasına girecek Osmanlıca, Arapça ve Grekçe gibi harf veya yazılar olursa dizgi operatörü göz kararıyla bir boşluk bırakır ve dizgiye devam eder.

Derginin en sonunda yer alan Kitabiyat kısmı, sayfaya karnıyarık dediğimiz uzunlamasına çift sütun ve 8 punto ile dizilir. Burada iki sütunun arasını açmak için araya asıl malzemesi alüminyum veya kurşun olan kadrat konur. Bir kadrat yarım santim ve iki kadrat bir santimdir. Tabii olarak üç kadrat, dört kadrat da konabilir. Ancak dergide iki kadrat daha fazla tercih edilir.

11 Matbaada kurşunun makine potasında eritilmesi esnasında çıkan buhar, zehirlenme riskini ortaya çıkarırdı. Bu bakımdan her yıl hastanede matbaa personelinin kandaki kurşun ölçümü düzenli olarak yapılırdı. Kurşun oranı fazla çıkanlar en az üç veya altı ay ücretli izine çıkarlardı. Zehirlenmeye karşı mesai saatleri içinde panzehir olarak yoğurt yeme arası verilirdi. 
Dergideki makalelerin içinde yer alan Osmanlıca, Arapça, Grekçe vb. harf veya yazılar matbaada Mürettiphane'de dizilirdi. Bu bakımdan Şevki Usta ve Adnan Usta tarafından Türkçe veya başka Latin alfabeli metinler dizildikten sonra makalelerin müsvedde metinleri Mürettiphane'nin dizgi kısmına geçerdi. O zaman bu kısımda yazılar mürettip Ali Müren ve Erol Diner tarafından dizilmekteydi. Gözlemlerimiz ve ustalarımızın verdiği bilgiler çerçevesinde burada dizgi için biri el, diğeri makine olmak üzere iki yöntem kullanıldığı görülür. Bizim dergimizde fazla Osmanlıca ve Arapça metinler olmadığı için genelde el ile dizgi yapılırdı. El ile yapılan dizgilerde kullanılacak kurşun ve lehim karışımı madenî harfler, çekmeceli bir kasanın gözleri içindeydi. Bu tür kasalara matbaacılık literatüründe hurufat kasası denir. Burada hurufât, harf kelimesinin çoğulu olan hurûfun çoğuludur. Kasa içindeki hurufat harfleri $6,8,10,12,16,18,20,24$ veya daha fazla punto (font) karakterindeydi. Dizgide mürettiplerimiz dipnotlar için genelde 6 punto, bazen 8 punto; normal metin içi yazılarda 10 veya 12 punto; makale başlıklarında ise 16 punto kullanır. 18, 20, 24 puntolar genel bazı yazılarda ve başlıklarda yer alır. Ayrıca bu harfler arasında italik, düz yani botanik denen beyaz ve koyu siyah olanlar da vardır.

Hurufat kasasındaki harflerin, kelime veya metin olarak dizildiği alete kumpas veya hurufat kumpası denir. Kumpas, satırın boyuna göre ayarlanabilir. İlk dizgide ustamız harfleri genelde el ile alarak kumpasın içine tek tek yerleştirir. Satırlar tamamlandıkça satır aralıklarının açılması ve harflerin dağılmaması için her satırın arasına antelin denen ve inceliği iki punto olan kurşun bir alet yerleştirilir. İlk dizgiden sonra metinde tashihler olur ise tashihi yapılacak harfler dizgi içinden çekilerek alınır ve yerine doğrusu yerleştirilir. Bu çekilme ve yerleştirilme işlemi çift adıyla bilinen, cımbıza benzeyen, çelikten yapılan, el ile kullanılan ve esneyebilen aletle yapılırdı. Osmanlıca ve Arapça metinlerin diziminde daha sonra matbaaya alınan entertype adlı makine kullanılmaya başlandı. Daktilo gibi harflerine el ile basılan makine, yazılan yazının her satırını eritilmiş sıvı kurşunla temas ettirmekte ve nihayetinde her satır kalıp halinde dışarıya mekanik olarak atılmaktaydı. Ancak Tarih Dergisi'nde Osmanlıca veya Arapça metinler genelde satır aralarında olduğu için el dizgisi tercih edilirdi.

Dizgi makinesinde satırlar kalıp halinde çıktıktan ve satırların içine veya arasına Osmanlıca, Arapça, Grekçe vb. harfler, kelimeler veya ifadeler girdikten sonra sayfaların bağlanması Mürettiphane'nin prova kısmında gerçekleşirdi. Burada sayfaları usulünce bağlayan ustalarımızdan Halil Coşkun ve Vural Yeşilyurt mürettip olarak bilinmekteydiler. O zamanda yaptığı işi dikkatle gözlemlediğimiz mürettiplerimizden Halil Coşkun ile yıllar sonra konuştuğumuzda hâlâ mesleğinin heyecanı içindeydi. Burada dizgi makinesinde dökülen satırlar kale denilen kalıbın içine yerleştirilirdi. Tarih Dergisi ölçeğinde söz konusu kalıp, bir sayfanın boyutunu içine alacak şekilde 26x40 veya 28x42 katratında/ebadında olur. Satırlar kalıba yerleştirilirken önceden dizilen Osmanlıca, Arapça ve Grekçe harf veya 
kelimeler de satır içine veya aralarına girer. Bu yerleştirmeler, dizgi operatörlerinin makale dizilirken harf veya yazı girecek kadar satırlarda bıraktıkları boşluklara yapılır. Boşluk birakılan yerler kopar denilen kesici aletle kesilir ve dizilen harfler, kelimeler veya ifadeler araya konur. Satırlar kalıbın içine yerleştirildikten sonra kalıbın dağılmaması için etrafı ip ile sıkı bir şekilde sarılır. Bu ip genelde kenevirden olur. Bu işlemden sonra prova tezgahında ilgili sayfanın bir provası alınır. Bunun için düz bir mermerin üzerine mürekkep damlatılır, el merdanesiyle mürekkep ezilir ve merdane satırlar halinde dizilen sayfa üzerinde el ile bastırılarak gezdirilir. Böylece mürekkep sayfanın tamamına eşit olarak dağılır. Bunu takiben sayfanın üzerine bir prova kâğıdı konur ve prova tezgâhının merdanesi arkadan öne doğru çekilerek prova alınmış olur. Muhtemelen bu uygulama erken dönem matbaacılığında kitap, gazete gibi baskılarda uygulanan sistemin daha gelişmiş hali olmalıdır.

Provası çekilen sayfalar, orijinal müsvedde metin ile karşılaştırılmak ve tashihleri yapılmak üzere hocamız Münir Aktepe'ye getirilirdi. Hocamız fakültede yazısı olan hocaların veya araştırıcıların yazılarının özellikle ilk tashihlerine kendilerinin bakmasını tercih ederdi. Ancak fakülte dışından gelen yazıların tashihlerinin çok fazla dağıtılmadan kendi içimizde yapılmasına öncelik verirdi. Daha önce belirtildiği gibi derginin başlıca yayın ilkesi, dergideki makalelerin mutlaka tek sayfada başlaması, çift sayfada sona ermesi ve iki makale arasında boş bir sayfa olmamasıdır. Bu sebepten sayfası bağlanmış ve provası çekilmiş makalelerin çift sayfada sona ermesine dikkat edilirdi. Eğer çift sayfada sona ermemiş bir makale olursa makale sahibinden çift sayfaya taşacak şekilde ara bir paragraf yazılması istenirdi. Tashihler esnasında tespit ettiğimiz önemli bir husus, ilk müsveddede sehven gözden kaçan yanlış bazı kelime veya harflerin, dizgi operatörleri tarafindan doğru olarak dizilmesiydi. Bu durum şüphesiz onların mesleklerinde çok donanımlı olduklarının bir işaretiydi. Dizilen satırlar soldan sağa kurşun dökme olduğu için satırlar arasında yanlış dizilen bir harfin tashihi çıkarsa, sadece o satır matbaada yeniden dizilirdi. Ancak bir satırda bir veya birkaç kelimenin ilave olması veya çıkarılması durumunda sadece o satırın değil, tashihli satırdan başlanarak paragraf sonuna kadar dizginin yeniden yapılması gerekirdi. Bu şekilde tashihli sayfalar birkaç defa dizgiye girebilir ve mürettipler tekrar prova çekmek durumunda kalabilirlerdi.

Derginin tashihleri tamamlandıktan sonra sıra basım işine gelirdi. Baskı ustası Ekrem Tanık, Şerif Yunker, Yüksel Bacak ve aynı zamanda mürettip de olan Halil Coşkun ile her an yüz yüze geliyor ve basım sürecini izliyorduk. Derginin standart baskı sayıs1 1.000 adetti. Ancak basım esnasında bazı sayfaların veya formaların bozuk çıkma ihtimali göz önüne alınarak baskı sayısı biraz yüksek tutulurdu. Baskı için genelde 75 gram birinci hamur kâğıt tercih edilirdi. Kâğıdın temin edilmesinden sonra her biri 16 sayfa olan formalar için $67 \times 49$ santim ebadında kâğıtlar Mücellithane'de kesilirdi. Matbaada iki baskı makinesi vardı. Bunlardan biri Alman Heidelberg, diğeri ise Japon malı baskı makinesi idi. Mürekkep olarak 
ise markasını şimdi hatırlayamadığımız tipo baskıya uygun matbaa mürekkebi kullanılırdı. Mürekkebin basılan formalarda soluk ve çok koyu değil, aynı standartta olmasına özen gösterilirdi.

16 sayfa olan bir formanın ön ve arka yüzleri 8'er sayfadır. Her yüz (8 sayfa) ayrı ayrı baskıya girer. Baskıya başlamadan önce kalıplar halindeki kelimelerin araları ve harflerin gözleri, mürekkep artıkları ve kalıntılarından arındırılırdı. Bunun için yazıların üzerine benzin dökülür ve firça ile bastırılarak temizlenirdi. Her forma için önlü arkalı ilk baskı numunesi alındıktan sonra harflerin gözlerinde kalıntı veya leke tespit edilirse bu defa toplu iğne ile çıkartılırdı. Sonra baskı ustalarımız formanın önlü arkalı tekrar baskısını yapardı. Temiz bir baskı çıkmışsa forma dergi ebadında katlanır ve hocamız Münir Aktepe'nin görmesi için bize teslim edilirdi. Hocamız baskıya girecek örnek formayı odasında kontrole başlamadan önce katlanmış formayı açarak masasının üstüne yayardı. Ön ve arka sayfalarda mürekkebin eşit olarak yayılıp yayılmadığını kontrol ederdi. Sonra bir satırın üzerine toplu iğne batırır ve toplu iğnenin arkadaki satırın tam üzerine gelip gelmediğine bakardı. Hatta bu uygulamayı birkaç satırın üzerinde de yapardı. Örnek formada herhangi bir şey yoksa formayı tekrar katlar, ilk sayfanın sağ üst köşesine "basıla" diye yazar ve altına imzasını atardı. Bu süreç içinde derginin basım işlemi devam eder ve tamamlanırdı.

Basım işi tamamlandıktan sonra formalar matbaanın Kırma Yeri de denen Mücellithane kısmına gelirdi. Burada basılan formaların katlanma ve ciltlenme işlemi yapılır. O zaman matbaada kırma makinesi olmadığından kırmalar el ile gerçekleşirdi. Bu bakımdan kırma işine el kırması denir. Mücellithane'de kırma işlemleri Mehmet Arman, Mustafa Koluaçık, Hüseyin Çakır, İsmail Saç tarafından yapılmaktaydı. Ayrıca burada özellikle cilt hususunda işinin ehli olan ustalarımızdan Namık Ünsal, Hulusi Alhan ve Arif Dülgeroğlu'nu da anmamız gerekir. Kırma işlemi ıstaka adlı bir aletle yapılır. Yassı olan ve zımpara ile perdahlanarak üzeri kayganlaşan bu aletin kemik olduğunu belirtmek gerekir. Nadir de olsa tahtadan da ıstaka olabilir. Ancak tahta ıstaka aşınmaya müsait olduğundan kullanım esnasında formalara zarar verebilir, kâğıdı zedeleyebilir ve hatta yırtabilirdi. Beyazımsı bir renkte olan kemik ıstaka, sabunun elden kaydığı gibi forma üzerinde kayardı. Bu sebepten ustabaşılarımız kemik sstaka aletini tercih ettiklerini söylerlerdi.

Forma kırılacağı zaman sağ ele ıstaka alınır, sol el ile formanın bir ucu, diğer ucun tam üzerine getirilir ve sağ eldeki ıstaka ile formanın özellikle kırılma yeri üzerine bastırılarak ilk katlama işi gerçekleşir. Sonra bu katlamayı ikinci, üçüncü katlamalar takip eder ve böylece forma dergi veya kitap boyuna gelmiş olur. Formaların düzgün kırılabilmesi için kırılma esnasında üst ve alt uçların mutlaka birbirinin üzerine ve sayfa rakamlarının birbirinin üstüne gelmesine özen gösterilir. Böylece 16 sayfadan ibaret olan bir forma üçe katlanmış olarak hazır bir hâle gelir. Yapılan bu işleme forma kırması denir. Derginin basımında olduğu gibi ciltlenmesinde de en temel unsur formadır. Bu bakımdan basımda, harmanlamada ve dikişte 
bir karışıklığa meydan vermemek için her formanın ilk başlangıç sayfasının altına Tarih Dergisi Forma 1, Tarih Dergisi Forma 2 gibi birbirini takip edecek şekilde forma numaraları yazılır.

Formaların kırılmasını takiben her forma sırayla birbirinin üzerine gelecek şekilde masanın üzerine dizilir. Bunu takiben el ile sonuncu formadan başlanarak ilk formaya kadar her formadan birer tane alınır ve müteselsil olarak formalar bir araya getirilir. Böylece derginin formaları bir bütün halinde bir araya getirilmiş olur. Bu işleme harman çekme denir. Harman çekme işlemi tamamlandıktan sonra formaların sırtlarından iplikle dikiş işlemine geçilir. Dikiş makinesi ile gerçekleşen dikiş işlemi, diğer ciltleme usullerine göre en uzun ömürlü olanıdır. Elektrikle çalışan bu makine, ayak pedalıyla idare edilir. Dergi veya kitaplar açıldığında dikişlerin formalar arasında gözükmemesi için ince naylon iplik kullanılır. Bir numara iplik çok ince; üç, dört, beş ve altı numara iplikler kalın düşeceğinden genelde iki numara iplik tercih edilir. Dikişlerde standart bir numaranın kullanılması önemlidir. Eğer dikiş esnasında bir türden farklı numaralı iplikler karışık şekilde kullanılırsa sırt ve formaların arası gevşek olur ve formalar arasında boşluklar meydana gelir ${ }^{12}$. Bu da eserin formalarının kısa bir süre içinde dağılmasına sebep olur.

Derginin her forması sırayla dikişe ayrı ayrı girer. Bu bağlamda ilk formadan başlanır ve son formaya kadar gelinir. Oturur vaziyette dikiş makinesini pedalıyla idare eden usta, her forma dikişe girdiğinde pedala bir defa basar. Her basmada formaya dört iğne iplikle beraber girer. Bu işlem son formaya kadar devam eder. Böylece derginin bir nüshasının dikişi tamamlanmış olur. İkinci nüshanın dikişine başlamadan önce pedala iki defa basılır; böylece arka arkaya gelen dergi nüshaları arasında bir boşluk veya gevşeklik bırakılır. Böylece dergi nüshalarının birbirinden kolayca ayrılması sağlanır. Derginin dikiş işlemi tamamlandıktan sonra iki pedal ile boşluk verilen dergi nüshaları arasındaki ipler makas veya jiletle kesilerek nüshalar birbirinden ayrılır. Bu arada ebadı ve sayfa kalınlığı belirlenmiş olan derginin kapak ölçüleri de alınır ve baskı makinesinde kapak baskısı yapılır.

Dikişten sonra sıra derginin bıçak veya giyotin denen aletle tıraşlanmasına gelir. Bu aletle önce derginin girintili çıkıntılı olan ve etek denen alt kısmı ve sonra ise baş denen ve daha düzgün olan üst kısmı tıraşlanır. Sonra derginin basılan kapağı, pilyaj makinesine girer. $\mathrm{Bu}$ makinede kapağın sırtına yakın yerden uzunlamasına ince bir iz veya oluk açılır. Bunu takiben

12 Bu bağlamda fakültemiz matbaasının mücellithanesinde ustabaşı olan Mehmet Arman'ın konuyla ilgili anlattığı bir olay hâlâ hatırımdadır: Fen Fakültesi'nde fakültemizdeki matbaaya benzer bir matbaa vardı. Bir gün Fen Fakültesi Sekreteri, fakültemiz sekreteri Vedat Çiftçili’ye telefon ederek fakültesindeki matbaanın dikiş makinesinde bir ârıza olduğunu ve forma dikişlerini çok gevşek yaptığını, ustalarının buna bir türlü çare bulamadığını söyler. Bunun üzerine Vedat Çiftçili bizim fakültenin matbaasına haber verir ve bu konuda bir ustanın gelmesini ister. Ustabaşı Mehmet Arman, Fen Fakültesi matbaasına gider ve incelemesi sonucunda makinede bir arıza olmadığını ve dikişte kullanılan iplerde ayrı ayrı numara kullanılmasından dolayı bu durumun meydana geldiğini belirtir ve böylece iş çözümlenmiş olur. 
kapakların dergiye takılma işlemine geçilir. Kapaklar takılırken derginin her bir nüshasının sırtına fırça ile beyaz kâğıt tutkalı sürülür ve kapaklar el ile geçirilir. Kapaklar geçirildikten sonra derginin sırt kısmı daha iyi tutması için ıstaka ile bastırılarak sıvazlanır. Bunu takiben dergi tekrar bıçağa girer ve takılan kapakla beraber bu defa ön yani ă̆ız kısmı tıraşlanır.

Derginin baskı işlemi tamamlandıktan sonra bütün sayılar ayniyata teslim edilirdi. Bunu takiben hocamız Münir Aktepe, yurt içindeki ve yurt dışındaki ilgili bilim insanlarına ve kurumlara gönderilmek üzere 150 civarında derginin verilmesi hususunda Dekanlığa bir yazı yazardı. Ayrıca dergiler, Fen Fakültesi'nin altındaki PTT şubesinden posta ile gönderileceğinden Dekanlıktan posta pulu, ambalaj kâğıdı ve paket ipi de istenirdi. Bu arada bir dergi örneği ile PTT’ye gidilir, yurt içi ve yurt dışı için üzerine kaç liralık pul yapışacağı öğrenilirdi. Bu işlerin tamamı kürsünün ve enstitünün genç elemanlarınca yapılırdı. Ayrıca hocamız dağıtım için İstanbul içinde elden verilecek ve posta ile yurt içine ve yurt dışına gönderilecek bilim insanlarının ve kurumların isim ve adreslerini gözden geçirirdi. Dekanlıktan dergiler, pul, ambalaj kâğıdı ve paket ipin gelmesini müteakip eldeki listeye göre paketleme işlerine başlanırdı. Bu paketleme işlerinde kâğıtlar bir dergiyi iki kat saracak şekilde kesilirdi. Ayrıca derginin gönderileceği bilim insanlarının ve kurumların adresleri, elimizdeki listeye göre kütüphane kataloglarındaki fişler ebadında kâğıtlara daktilo ile yazılırdı. Yazımı takiben arkası zamklanan adres kâğıtları, ambalaj kâğıdı ile düzgünce paketlenen ve iple sarılan her bir dergi paketinin sağ alt köşesine yapıştırılırdı. Paketin sol üst köşesine ise Tarih Araştırmaları Enstitüsü'nün adresini belirten damga vurulurdu. Paketleme işleminden sonra isimler ve adresler çift kopyalı tutanak defterine posta ücretleriyle beraber yazılır ve Fen Fakültesi'nin altındaki PTT'ye teslim edilirdi. Burada çift kopyalı tutanak kâğıdının bir kopyası PTT'de kalmak üzere mühürlenir ve böylece işlem tamamlanırdı.

$\mathrm{Bu}$ işlemlerin Yeniçağ Tarihi Kürsüsü ve Tarih Araştırmaları Enstitüsü mensuplarınca zevkle yapıldığını öncelikle belirtmem gerekir. Her şeyden önce mesleğimizin ilk yıllarında iletişim ağı bugünkü gibi dünyayı sarmalamış bir durumda değildi. Dolayısıyla alanında uzman pek çok tarihçinin ismini bile bilemiyorduk. Bu bağlamda her biri alanında seçkin bilim insanı olan Enver Ziya Karal, Bekir Sıdkı Baykal, Mehmet Altay Köymen, Faruk Sümer, Akdes Nimet Kurat, Yuluğ Tekin Kurat, Osman Ersoy, Halil İnalcık, Ercüment Kuran, Orhan Şaik Gökyay, Bernard Lewis, Victor Ménage, V. John Parry, Stanford Show gibi bilim insanlarına dergilerin gönderilmesi, onları daha sonra tanıma imkânımız olsa da önceden ismen bilmemize ve tanımamıza yardımcı olmaktaydı.

Tarih Dergisi'nin az da olsa bir kısmı elden dağıtılırdı. Bu bağlamda Osmanlı tarihinin duayenlerinden Ömer Lütfi Barkan, Halil Sahillioğlu, Bayezid Kütüphanesi Müdürü Muzaffer Gökman, o zaman Osmanlı Arşivi (bugünkü Başkanlık Osmanlı Arşivi) Müdürü olan Midhat Sertoğlu, İbrahim Artuk ve İsmail Hakkı Uzunçarşılı gibi bilim insanlarına dergiler elden sunulurdu. Dergilerin sunumu esnasında bu duayen hocalarımızla konuşma imkânımız da 
olurdu. Bu bağlamda derginin bir sayısını İsmail Hakkı Uzunçarşılı’ya sunmak üzere Topkapı Sarayı Müzesi Arşivi'ne gittiğimde, Uzunçarşılı Hoca'nın ayak üstü de olsa benimle kısa bir konuşma yapması, hayatımda unutamayacağım bir anı oldu. Hocamıza dergiyi sunduktan sonra önce derginin münderecatına kısaca baktı ve sonra yüzüme bakarak: "Sen kiminle tez hazırlyyorsun" dedi. "Benim tez hocam Cengiz Orhonlu'dur. Hocamin nezaretinde tez hazırlıyorum" dedim ve arkasından hemen ekledi: "Çok iyi bir hoca ile çalışıyorsun".

1949 yılında tesis edilen Tarih Dergisi'nin bugüne kadar 70 sayısının yayınlanmış olması ${ }^{13}$, şüphesiz Tarih Bölümü’nde kurumsallaşma temelinin çok sağlam atıldığının bir göstergesidir. Bugün bilgisayar ortamında genelde bir dergi veya kitap bir kişinin bir koldan çalışmasıyla basıma hazır bir hâle gelirken bizzat içinde yaşadığımız 1970'li yılların ortamında ve hatta daha önceki yıllarda dergiler bir ağacın gövdesindeki dallar ve budaklar gibi muhtelif kolların uyumlu çalışmasıyla yayımlanabilmekteydi. Ancak bu çalışma uzun ve ince bir yolun kat edilmesini icap ettiriyordu. Bu ince yolu kat etmek ise kolların ekip ruhu içinde çalışmasıyla mümkün olabilmekteydi. Ekibin içinde sadece bölümde dergiyle uğraşan hocalarımız ve meslektaşlarımız değil, vefat edenlerine Allah'tan rahmet, hayatta olanlarına uzun ömürler dilediğimiz fakültemiz matbaasının müdürlerinden Nazım Tahaoğlu, Önder Orhon, Ahmet Avc1, Hürol Özelsel ve Yaşar Ulu ile derginin matbaadaki basım süreci içinde kendilerinden çok şeyler öğrendiğimiz matbaa personelinden Adnan Adsız, Ali Şevki Bengi, Ali Müren, Erol Diner, Halil Coşkun, Vural Yeşilyurt, Ekrem Tanık, Şerif Yunker, Yüksel Bacak, Mehmet Arman, Mustafa Koluaçık, Hüseyin Çakır, İsmail Saç, Namık Ünsal, Hulusi Alhan, Bekir Özbay ve Arif Dülgeroğlu gibi ustalarımız vardı. Bu ekip çalışmasının başarısında şüphesiz bir orkestra şefi gibi çalışanlar arasında aynı sesin çıkmasını sağlayan, saygı ve sevgi köprüsünü kuran merhum hocalarımızı burada yad etmek gerekir.

Hakem Değerlendirmesi: Dış bağımsız.

Çıkar Çatışması: Yazar çıkar çatışması bildirmemiştir.

Finansal Destek: Yazar bu çalışma için finansal destek almadığını beyan etmiştir.

Peer-review: Externally peer-reviewed.

Conflict of Interest: The author has no conflict of interest to declare.

Grant Support: The author declared that this study has received no financial support.

13 Belli bir sayıya kadar dergide yer alan makalelerin künyeleri için bk. Erdoğan Merçil, "İstanbul Üniversitesi Edebiyat Fakültesi Tarih Dergisi Tahlili Bibliyografyası: 1949-1971”, TD, say1 25 (1971), s. 221-238; Arzu T. Terzi, "İstanbul Üniversitesi Edebiyat Fakültesi Tarih Dergisi Bibliyografyası: 1972-2000”, TD, sayı 37 (2002), s. 403-433; derginin 1-48. sayılarındaki makalelerin bibliyografyası için bk. Mahmut Ak-Soner Demirsoy, "İstanbul Üniversitesi Edebiyat Fakültesi Tarih Dergisi Bibliyografyası: Say1 1-48", TD, sayı 50 (2009), s. 275-336. 


\section{Kaynakça/References}

Ak, Mahmut, “50. Sayısında İstanbul Üniversitesi Tarih Dergisi”, Tarih Dergisi, say1 50 (2009), s. 259-273. , "Tarih Dergisi”, DİA, XL (2011), 79-80.

- Soner Demirsoy, "İstanbul Üniversitesi Edebiyat Fakültesi Tarih Dergisi Bibliyografyası: Sayı

1-48”, Tarih Dergisi, say1 50 (2009), s. 275-336.

Aktepe, M. Münir, “Baysun, Mehmet Cavit (1899-1968)”, DİA, V (1992), 275-276.

, "Ord. Prof. M. Cavid Baysun”, Belleten, XXXIII/129 (1969), s. 97-113.

Albayrak, Nurettin, “Darülfünun Edebiyat Fakültesi Mecmuası”, DİA, VIII (1993), 525-526.

Arıkan, Zeki, "Yitirdiğimiz Büyük Değer. Münir Aktepe'nin Ardından”, Tarih ve Toplum, sayı 153 (1996), s. 4-8.

Başar, Fahameddin, “Darülfünun Edebiyat Fakültesi Mecmuası'ndaki Makaleler ve Yazarları”, Tarih Dergisi,

say1 38 (2003), 183-234.

Beydilli, Kemal, “Matbaa”, DİA, XXVIII (2003), 105-110.

Cumhuriyetin 50. Yllında İstanbul Üniversitesi, haz. İstanbul Üniversitesi, İstanbul 1973, s. 435-463.

Emecen, Feridun, “Aktepe, M. Münir”, DİA, EK-1 (2016), 67-68.

"Prof. Dr. Münir Aktepe'nin Akademik Hayatı", Münir Aktepe, İzmir Yazılarl: Camiler, Hanlar, Medreseler, Sebiller içinde, haz. Fikret Yılmaz, İzmir 2003, s. XXXV-XXXIX.

Göyünç, Nejat, "Cengiz Orhonlu Hayatı-Eserleri-Şahsiyeti”, Türk Kültürü Araştırmalarl, XV/1-2 (1976), s. 7-32.

Güleç, İsmail, “Türkiyat Mecmuası”, DİA, XLI (2012), 561-562.

Halaçoğlu, Yusuf, “Hocam Cengiz Orhonlu”, Güney-Doğu Avrupa Araştırmaları Dergisi, XII (1998), s. XI-XIII.

İçtimâiyât Mecmuası, yay. haz. Mehmet Kanar, sayı 1-6, Edebiyat Fakültesi Basımevi, İstanbul 1997.

İlgürel, Mücteba, "Prof. Dr. Münir Aktepe'nin Hayatı ve Eserleri”, Tarih Enstitüsü Dergisi, sayı 15 (1997), s. $1-14$.

Köprülü, Orhan F., “Ord. Prof. Cavid Baysun’un Ardından”, Tarih Dergisi, sayı 23 (1969), s. 9-12.

Merçil, Erdoğan, "İstanbul Üniversitesi Edebiyat Fakültesi Tarih Dergisi Tahlili Bibliyografyası: 1949-1971”, Tarih Dergisi, say1 25 (1971), s. 221-238.

Orhonlu, Cengiz, “Edebiyat Fakültesi'nin Kuruluşu ve Gelişmesi (1901-1933) Hakkında Bazı Düşünceler”, Cumhuriyetin 50. Yllına Armağan, haz. İstanbul Üniversitesi Edebiyat Fakültesi, İstanbul 1973, s. 57-70.

Şahin, İlhan, “Orhonlu, Cengiz”, DIA, XXXIII (2010), 393-394.

Şakiroğlu, Mahmut H., "Prof. Dr. Cengiz Orhonlu 1927-1976”, Belleten, XL/160 (1976), s. 669-686.

Şentürk, Recep, “İctimâiyyat Mecmuası”, DİA, XXI (2000), 448-449.

Tarhan, M. Taner - Ömer Faruk Akün, "Edebiyat Fakültesi”, DIA, X (1994), 399-403.

Tekin, Oğuz - Nil Türker Tekin, Mülteci Bir Akademisyenin Biyografisi Clemens Emin Bosch (1899-1955), Suna-İnan Kıraç Akdeniz Medeniyetleri Araştırma Enstitüsü, İstanbul 2007.

Tekindağ, M. C. Şehabeddin, “Kaybettiğimiz Bir Değer: Ord. Prof. M. Cavid Baysun”, Tarih Dergisi, say1 23 (1969), s. 1-8.

, "Kaybettiğimiz Bir Değer Cengiz Orhonlu”, Tarih Dergisi, sayı 30 (1976), s. 1-8.

Terzi, Arzu T., "İstanbul Üniversitesi Edebiyat Fakültesi Tarih Dergisi Bibliyografyası: 1972-2000", Tarih Dergisi, say1 37 (2002), s. 403-433. 